\title{
Pengaruh Penggunaan Internet Terhadap Minat dan Motivasi Belajar Dengan Mempertimbangkan Jenis Kelamin
}

\author{
Ibnur Rusi ${ }^{1}$ \\ ${ }^{1}$ Sekolah Tinggi Ilmu Ekonomi Mulia Singkawang \\ ibnuremail@gmail.com
}

\begin{abstract}
Fasilitas teknologi dan jaringan internet, serta kemudahan dalam mengaksesnya pada perguruan tinggi diharapkan dapat menjadi wadah yang baik bagi mahasiswa untuk kemudian dimanfaatkan guna meningkatkan kualitas pembelajaran mereka. Melalui fasilitas internet yang disediakan oleh perguruan tinggi, mahasiswa dapat mengakses segala macam bentuk informasi untuk memenuhi kebutuhan ilmu dan mengerjakan tanggungjawabnya, tetapi pemanfaatan internet sering disalahgunakan untuk hal yang tidak berguna yang tidak ada kaitannya untuk menunjang pembelajaran, seperti mengakses media sosial dan bermain game online. Oleh karena itu perlu dilakukan penelitian untuk mengetahui pengaruh penggunaan internet terhadap minat dan motivasi belajar dengan mempertimbangkan jenis kelamin. Penelitian ini dilakukan di Sekolah Tinggi Ilmu Ekonomi (STIE) Mulia Singkawang dengan menggunakan pendekatan model TAM (Technology Acceptance Model), sedangkan untuk menguji validitas dan realibilitas menggunakan software SPSS. Hasil dari penelitian membuktikan bahwa kemudahan penggunaan dan manfaat penggunaan internet berpengaruh terhadap minat belajar mahasiswa dan minat belajar berpengaruh terhadap motivasi belajar mahasiswa. Sedangkan hasil dari mahasiswi variabel kemudahan penggunaan tidak berpengaruh terhadap minat belajar mahasiswi akan tetapi kemudahan penggunaan internet berpengaruh terhadap minat belajar mahasiswi dan minat belajar mahasiswi mempengaruhi motivasi belajar mahasiswi. Hasil dari penelitian ini diharapkan dapat menjadi masukan bagi STIE Mulia untuk memaksimalkan penggunaan internet guna mendukung kegiatan pembelajaran.
\end{abstract}

Kata kunci: Penggunaan Internet, Minat, Motivasi, TAM

Technology facilities and internet networks, as well as ease of accessing them in higher education are expected to provide a good place for students to be used to improve the quality of their learning. Through internet facilities provided by tertiary institutions, students can access all kinds of information to meet their knowledge needs and carry out accountability, but internet assistance is often misused for things that do not require assistance to support learning, such as accessing social media and playing online games. Therefore it is necessary to conduct research to determine the use of the internet to interest and motivation to learn with gender considerations. This research was conducted at the College of Economics (STIE) Mulia Singkawang using the TAM (Technology Acceptance Model) model, while to obtain validity and reliability using SPSS software. The results of the research prove about the use and benefits of using the internet for student interest and learning interest in student motivation. Meanwhile, the results of this study use variables related to interest in learning, but how to use them for learning purposes. The results of this study are expected to be input for STIE Mulia to maximize the use of the internet to support learning activities.

Keywords: Internet use, Interests, Motivation, TAM

(C) 2019 JBTI. All rights reserved

Article history : Received 2 Agustus 2019; Revised 10 Agustus 2019; Accepted 12 Agustus 2018

\section{PENDAHULUAN}

Internet merupakan hal yang sangat penting bahkan dapat dikatakan sebagai kebutuhan di zaman modern seperti sekarang ini. Banyak sekali tempat-tempat yang memberikan fasilitas 
internet untuk kemudahan interaksi, menyelesaikan tugas bahkan untuk menarik konsumen. Demikian pula yang dilakukan oleh lembaga-lembaga pendidikan, mereka berlomba-lomba menyediakan fasilitas internet untuk memudahkan dan meningkatkan kinerja dari stakeholder yang terlibat dalam lembaga tersebut. Saat ini hampir seluruh Perguruan Tinggi (PT) di Indonesia baik negeri maupun swasta memanfaatkan internet untuk bersaing dalam mengembangkan sistem pembelajarannya, salah satu cara untuk mengembangkan sistem pembelajaran adalah dengan memanfaatkan perkembangan dan kemudahan teknologi internet. Pemilihan penggunaan internet disebabkan karena selain fleksibel, internet juga dapat digunakan sebagai media untuk mencari informasi. Dengan menggunakan internet, seseorang dapat mengetahui berbagai hal yang ada di seluruh penjuru dunia. Pada PT hak akses jaringan internet diberikan kepada seluruh civitas akademika, tanpa terkecuali termasuk mahasiswa. Sehingga mahasiswa dapat dengan bebas mengakses fasilitas internet yang disediakan kampus kapanpun mereka mau.

Dengan adanya fasilitas dan kemudahan mengakses internet yang telah disediakan PT seharusnya dimanfaatkan dengan baik oleh mahasiswa guna menunjang perkuliahan seperti menyelesaikan tugas dan mencari referensi, sehingga dapat menumbuhkan minat dan motivasi belajar mereka. Dengan penggunaan dan pemanfaatan yang tepat dan sesuai diharapkan dapat menambah wawasan ilmu serta meningkatkan prestasi belajar mereka. Tetapi pada kenyataannya pemanfaatan internet di lingkungan kampus sering disalahgunakan oleh mahasiswa. Mahasiswa tidak hanya menggunakan fasilitas internet untuk menunjang proses akademik, tetapi mereka lebih sering menggunakan internet tersebut untuk hal non-akademik, seperti mengakses jejaring media sosial, bermain game online, dan membuka situs-situs yang tidak ada hubungannya dengan akademik.

Penelitian ini dilakukan di Sekolah Tinggi Ilmu Ekonomi (STIE) Mulia Singkawang yang merupakan salah satu PT yang sangat concern terhadap dunia pendidikan, khususnya pendidikan tinggi di Kota Singkawang. Objek dalam penelitian ini adalah peserta didik (mahasiswa dan mahasiswi). Dengan memisahkan atau mempertimbangkan jenis kelamin dalam penelitian ini, peneliti tertarik untuk mengetahui perbedaan penggunaan atau pemanfaatan internet antara mahasiswa (peserta didik laki-laki) dan mahasiswi (peserta didik perempuan) di STIE Mulia Singkawang, sehingga peneliti mengambil judul "Pengaruh Penggunaan Internet Terhadap Minat Dan Motivasi Belajar Dengan Mempertimbangkan Jenis Kelamin".

Penelitian terdahulu yang menjadi referensi dari penelitian ini adalah penelitian dari Ricoida \& Pibriana (2016) dengan judul "Pengaruh Penggunaan Internet Terhadap Minat Dan Perilaku Belajar Mahasiswa". Model yang digunakan dalam penelitian tersebut adalah model Theory of Reasoned Action (TRA), dan terdiri dari tiga hipotesis yaitu Sikap penggunaan internet berpengaruh secara positif pada minat belajar mahasiswa $\left(\mathrm{H}_{1}\right)$, Norma Subjektif tentang penggunaan Internet berpengaruh positif terhadap minat belajar mahasiswa $\left(\mathrm{H}_{2}\right)$, dan Minat Belajar mahasiswa berpengaruh positif terhadap perilaku belajar mahasiswa $\left(\mathrm{H}_{3}\right)$. Hasil dari penelitian menyatakan bahwa ketiga hipotesis mempunyai estimasi yang positif yang berarti seluruh hipotesis diterima. Hal ini menandakan bahwa sikap dan norma subjektif dalam penggunaan internet berpengaruh terhadap minat belajar mahasiswa, dan minat belajar mahasiswa berpengaruh positif terhadap perilaku belajar mahasiswa.

Penelitian lain yang menjadi referensi peneliti adalah penelitian dari Widiatika \& Sensuse (2008) dengan judul "Pengembangan Model Penerimaan Teknologi Internet Oleh Pelajar Dengan Menggunakan Konsep Technology Acceptance Model (TAM)". Objek penelitian dalam penelitan tersebut adalah pelajar sekolah menengah atas (SMA sederajat) dan variabel yang digunakan adalah penggunaan internet yang menjadi indikator untuk mengukur sikap penggunaan internet dan perhatian untuk menggunakan internet. Hasil yang didapatkan menunjukkan bahwa Internet memberikan pengaruh positif terhadap tingkah laku pelajar dalam memanfaatkan internet. 


\section{a. Rumusan Masalah}

Berdasarkan latar belakang masalah yang telah diuraikan mengenai pengaruh penggunaan internet terhadap minat dan motivasi belajar, maka rumusan masalah dari penelitian ini adalah:

1) Apakah ada pengaruh kemudahan akses dan pemanfaatan internet terhadap minat dan motivasi belajar mahasiswa dan mahasiswi?

2) Seberapa besar pengaruh kemudahan akses dan pemanfaatan internet terhadap minat dan motivasi belajar mahasiswa dan mahasiswi?

\section{b. Batasan Masalah}

Pada penelitian ini peneliti membatasi obyek penelitian hanya pada mahasiswa dan mahasiswi STIE Mulia Singkawang, penggunaan internet meliputi kemudahan penggunaan dan manfaat penggunaan, serta minat dan motivasi belajar.

\section{KAJIAN TEORI}

\section{a. Internet}

Menurut Greenlaw and Hepp (2002: 98), internet adalah sebuah sistem informasi global yang terhubung secara logika oleh address yang unik secara global yang berbasis pada Internet Protocol (IP), mendukung komunikasi dengan menggunakan TCP/IP, menyediakan, menggunakan, dan membuatnya bisa diakses baik secara umum maupun khusus.

\section{b. Minat}

Minat merupakan keinginan seseorang untuk melakukan suatu perilaku tertentu (Jogiyanto, 2007). Minat berkaitan dengan perasaan suka atau senang dari seseorang terhadap sesuatu objek. Hal ini seperti yang dikemukakan oleh Slameto (2003:180) yang menyatakan bahwa minat sebagai suatu rasa lebih suka dan rasa keterikatan pada suatu hal atau aktivitas, tanpa ada yang menyuruh.

Peserta didik yang berminat dalam berlajar mempunyai ciri-ciri, yakni tekun menghadapi tugas, ulet menghadapi kesulitan, menunjukkan minat terhadap bermacammacam masalah belajar, lebih senang bekerja mandiri, tidak cepat bosan dengan tugastugas rutin, dapat mempertahankan pendapatnya, tidak mudah melepaskan apa yang diyakini, senang mencari dan memecahkan masalah (Sardiman, 2011). Sardiman juga menyatakan bahwa "minat timbul tidak secara tiba-tiba atau spontan, melainkan timbul akibat dari partisapasi, pengalaman, kebiasaan pada waktu belajar untuk bekerja".

\section{c. Motivasi}

Menurut Mc. Donald, yang dikutip Sardiman (2007: 73), motivasi diartikan sebagai perubahan energi dalam diri seseorang yang ditandai dengan munculnya "feeling" dan didahului dengan tanggapan terhadap adanya tujuan. Menurut Greenberg dan Baron, yang dikutip Khairani (2014: 176), motivasi adalah suatu proses yang mendorong, mengarahkan, dan memelihara perilaku manusia kearah pencapaian tujuan dan segala yang ada di dalam diri manusia untuk membentuk motivasi. Menurut Sumadi Suryabrata dikutip oleh Djaali (2013:101), motivasi didefinisikan sebagai keadaan yang terdapat dalam diri seseorang yang mendorongnya untuk melakukan aktifitas tertentu guna pencapaian suatu tujuan. 


\section{d. Belajar}

Menurut Syah, yang dikutip Jihad dan Haris (2012: 1), belajar adalah tahapan perubahan perilaku yang relative positif dan mantap sebagai hasil interaksi dengan lingkungan yang melibatkan proses kognitif. Belajar juga diartikan sebagai proses usaha yang kompleks yang dilakukan oleh seseorang untuk memperoleh perubahan tingkah laku yang lebih baik secara keseluruhan akibat Interaksi dengan lingkungannya (Hanifah \& Abdullah, 2001)

Menurut Irwanto, yang dikutip Khairani (2014: 4), belajar adalah proses perubahan dari belum menjadi sudah mampu dan terjadi dalam jangka waktu tertentu. Sedangkan menurut Morgan, yang dikutip Khairani (2014: 4), belajar adalah perubahan yang relatif menetap dalam tingkah laku yang terjadi sebagai hasil dari latihan.

\section{e. Motivasi Belajar}

Menurut Dimyati dan Mudjiono (2009: 80) motivasi belajar diartikan sebagai kekuatan mental yang mendorong terjadinya belajar atau dorongan mental yang menggerakkan dan mengarahkan perilaku manusia (perilaku belajar).

Motivasi dan belajar merupakan dua hal yang saling mempengaruhi. Motivasi belajar dapat timbul karena faktor intrinsik, berupa hasrat dan keinginan berhasil dan dorongan kebutuhan belajar, harapan akan cita-cita. Sedangkan faktor ekstrinsik adalah adanya penghargaan, lingkungan belajar yang kondusif, dan kegiatan belajar yang menarik (Hamzah, 2008)

\section{f. Technology Acceptance Model (TAM)}

Technologi Accpetance Model (TAM) merupakan model yang digunakan untuk memprediksi penerimaan pengguna terhadap penggunaan teknologi. Model ini dikenalkan oleh Fred D. Davis pada tahun 1989 dan merupakan model yang paling banyak digunakan dalam penelitian sistem informasi. TAM merupakan adaptasi dari teori Theory of Reasoned Action (TRA) yang merupakan teori tindakan yang berlandaskan dengan satu asumsi bahwa reaksi dan persepsi seseorang terhadap suatu hal akan menentukan sikap dan perilaku orang tersebut (Tjahjono \& Wulandari, 2008).

TAM menggambarkan hubungan antara (Davis, 1989): (1) Perceived Ease to Use $(P e o U)$ : menyatakan tingkat kepercayaan bahwa teknologi baru akan mudah dipakai dan terbebas dari usaha, (2) Percieved Usefulness (PU): menyatakan tingkat kepercayaan bahwa penggunaan teknologi baru akan meningkatkan pencapaian, (3) Attitude Toward Using (ATU): menyatakan sikap pengguna (user) ke arah menggunakan teknologi baru, (4) Behavioral Intention to Use (ITU): menyatakan perilaku pengguna (user) kearah berlanjutnya penggunaan sebuah teknologi baru yang dianggap memberikan manfaat, (5) Actual System Usage (ASU) : menyatakan pengguna (user) benar - benar menggunakan teknologi baru secara nyata karena merasakan manfaatnya (Winarno, 2004).

\section{METODE PENELITIAN}

Jenis penelitian yang digunakan dalam penelitian ini adalah jenis penelitan dengan pendekatan kuantitatif, sedangkan metode yang dipakai adalah survey. Menurut Sugiyono (2013) penelitian survey adalah penelitian yang dilakukan dengan menggunakan populasi besar maupun kecil, tetapi data yang dipelajari adalah data dari sampel yang diambil dari populasi tersebut, untuk menemukan kejadian-kejadian relatif, distribusi dan hubungan-hubungan antar variabel 
sosiologis maupun psikologis. Adapun teknik pengumpulan data yang dilakukan dengan menyebar kuesioner kepada responden. Responden yang diminta untuk mengisi kuisioner adalah mahasiwa dan mahasiswi STIE Mulia Singkawang, sedangkan sample penelitian diambil secara random (random sampling).

Kuesioner atau angket merupakan cara pengumpulan data dengan memberikan daftar pertanyaan kepada responden untuk kemudian diisi. Adapun pengukuran yang digunakan dalam penelitian ini adalah skala likert. Skala likert yang digunakan untuk mengukur sikap, pendapat, dan persepsi seseorang atau kelompok orang tentang fenomena sosial. Skala pengukuran digunakan sebagai acuan untuk menentukan panjang pendeknya rentang yang ada dalam alat ukur.

Model yang digunakan dalam penelitian ini adalah model Technology Acceptance Model (TAM) dengan mengambil 2 variabel, yaitu Percieved Usefulness (PU) atau manfaat pengunaan (internet) dan Percivied Ease of Use (PeoU) atau kemudahan penggunaan (internet), yang diuji untuk mengetahui pengaruh 2 variabel yaitu minat dan motivasi belajar mahasiswa, dengan mempertimbangkan jenis kelamin mahasiswa.

\section{Uji Validitas}

Menurut Priyatno (2016: 143) : "Uji validitas digunakan untuk mengetahui seberapa cermat suatu instrumen atau item-item dalam mengukur apa yang ingin diukur". Item kuesioner yang tidak valid berarti tidak dapat mengukur apa yang ingin diukur sehingga hasil yang didapat tidak dapat dipercaya, sehingga item yang tidak valid harus dibuang atau diperbaiki.

Perhitungan validitas dilakukan dengan bantuan program SPSS versi 22 dalam penelitian ini menggunakan taraf signifikan sebesar 0,05. Analisis butir dilakukan untuk mengetahui valid atau tidaknya item dalam instrumen dengan cara yaitu skor-skor yang ada pada item dikorelasikan dengan skor total, kemudian dibandingkan pada taraf signifikasi 0,05 .

\section{Uji Realiabilitas}

Menurut Priyatno (2016: 154) : "Uji reliabilitas digunakan untuk menguji konsistensi alat ukur, apakah hasilnya tetap konsisten atau tidak jika pengukuran diulang". Instrumen kuesioner yang tidak reliabel maka tidak konsisten untuk pengukuran sehingga hasil pengukuran tidak dapat dipercaya. Perhitungan reliabilitas dilakukan dengan bantuan program SPSS versi 22 suatu instrument dinyatakan realiabel jika memiliki nilai $r$ hitung $>r$ tabel.

\section{Uji Asumsi Klasik}

Menurut Priyatno (2016: 117) berikut beberapa uji asumsi klasik yaitu:

1) Uji Normalitas Residual

Uji ini dilakukan untuk mengetahui apakah dalam sebuah model regresi, nilai residual memiliki distribusi normal atau tidak. Residual adalah nilai selisih antara variabel $\mathrm{Y}$ dengan variabel Y yang diprediksikan.

2) Uji Multikolinearitas

Multikolinearitas adalah keadaan dimana antara dua variabel independen atau lebih pada model regresi terjadi hubungan linier yang sempurna atau mendekati sempurna. Model regresi yang baik mensyaratkan tidak adanya masalah multikolinearitas.

3) Uji Heterokedastisitas

Heteroskedastisitas adalah keadaan dimana terjadinya ketidaksamaan varian dari residual pada model regresi. Model regresi yang baik mensyaratkan tidak adanya masalah heteroskedastisitas. 


\section{Analisis Regresi Linier Berganda}

Analisis regresi linier berganda digunakan untuk mengetahui pengaruh antara dua atau lebih variabel bebas (X) dengan satu variabel terikat (Y). Analisis regresi linier berganda menggunakan dua atau lebih variabel bebas yang dimasukkan dalam model regresi. Analisis ini juga mengetahui arah hubungan antara variabel bebas dengan variabel terikat apakah masingmasing variabel bebas berhubungan positif atau negatif. Berikut ini persamaan regresi linear berganda:

$$
\mathrm{Y}=\mathrm{a}+\mathrm{b} 1 \mathrm{X} 1+\mathrm{b} 2 \mathrm{X} 2+\mathrm{b} 3 \mathrm{X} 3 \ldots+\mathrm{bnXn}
$$

\section{Uji Model}

1) Uji F

Menurut Priyatno (2016: 63) : "Uji F digunakan untuk menguji pengaruh variabel independen secara bersama-sama terhadap variabel dependen".

2) Uji t

Menurut Priyatno (2016: 63) : "Uji t digunakan untuk menguji pengaruh variabel independen secara parsial terhadap variabel dependen".

\section{HASIL DAN PEMBAHASAN}

Pada bagian ini dijelaskan mengenai analisis dan pembahasan serta pengolahan data statistik serta pengujian model. Tingkat signifikansi yang digunakan pada pengujian yang dilakukan adalah sebesar 0.05 atau 5\% sehingga tingkat kepercayaan pada penelitian ini sebesar $95 \%$.

\section{Uji Validitas}

Untuk menguji Validitas, dilakukan perbandingan antara nilai corrected item-total correlation pada setiap indikator atau pertanyaan dengan nilai $\mathrm{r}$ tabel. Jika corrected item-total correlation ( $\mathrm{r}$ hitung) bernilai positif dan lebih besar dari nilai $\mathrm{r}$ tabel, maka indikator atau pertanyaan pada variabel dapat dikatakan valid.

Tabel 4.1

Uji Validitas Jenis Kelamin Laki-Laki

\begin{tabular}{|c|c|c|c|c|}
\hline Variabel & Indikator & Frekuensi & Sig. & Keterangan \\
\hline \multirow{3}{*}{$\begin{array}{c}\text { Kemudahan } \\
\text { Penggunan }\end{array}$} & 1 & 0,464 & 0,005 & Valid \\
\cline { 2 - 5 } & 2 & 0,519 & 0,001 & Valid \\
\cline { 2 - 5 } & 3 & 0,661 & 0,000 & Valid \\
\cline { 2 - 5 } & 4 & 0,548 & 0,001 & Valid \\
\cline { 2 - 5 } & 1 & 0,773 & 0,000 & Valid \\
\cline { 2 - 5 } & 2 & 0,631 & 0,000 & Valid \\
\cline { 2 - 5 } Manfaat & 3 & 0,546 & 0,001 & Valid \\
\cline { 2 - 5 } & 4 & 0,545 & 0,001 & Valid \\
\cline { 2 - 5 } & 5 & 0,477 & 0,004 & Valid \\
\cline { 2 - 5 } & 6 & 0,533 & 0,004 & Valid \\
\cline { 2 - 5 } & 1 & 0,652 & 0,000 & Valid \\
\cline { 2 - 5 } & 2 & 0,616 & 0,000 & Valid \\
\cline { 2 - 5 } Minat & 3 & 0,782 & 0,000 & Valid \\
\cline { 2 - 5 } Belajar & 4 & 0,769 & 0,000 & Valid \\
\cline { 2 - 5 } & & 0,635 & 0,000 & Valid \\
\hline
\end{tabular}




\begin{tabular}{|c|c|c|c|c|}
\hline \multirow{4}{*}{} & 5 & 0,751 & 0,000 & Valid \\
\cline { 2 - 5 } & 6 & 0,669 & 0,000 & Valid \\
\cline { 2 - 5 } & 7 & 0,642 & 0,000 & Valid \\
\hline \multirow{4}{*}{$\begin{array}{c}\text { Motivasi } \\
\text { Belajar }\end{array}$} & 8 & 0,764 & 0,000 & Valid \\
\cline { 2 - 5 } & 2 & 0,737 & 0,000 & Valid \\
\cline { 2 - 5 } & 2 & 0,552 & 0,001 & Valid \\
\cline { 2 - 5 } & 4 & 0,528 & 0,000 & Valid \\
\cline { 2 - 5 } & 5 & 0,663 & 0,000 & Valid \\
\cline { 2 - 5 } & 7 & 0,479 & 0,004 & Valid \\
\cline { 2 - 5 } & 8 & 0,659 & 0,000 & Valid \\
\hline
\end{tabular}

Tabel 4.2

Uji Validitas Jenis Kelamin Perempuan

\begin{tabular}{|c|c|c|c|c|}
\hline Variabel & Indikator & Frekuensi & Sig. & Keterangan \\
\hline \multirow{4}{*}{$\begin{array}{l}\text { Kemudahan } \\
\text { Penggunan }\end{array}$} & 1 & 0,691 & 0,000 & Valid \\
\hline & 2 & 0,527 & 0,001 & Valid \\
\hline & 3 & 0,575 & 0,000 & Valid \\
\hline & 4 & 0,609 & 0,000 & Valid \\
\hline \multirow{7}{*}{$\begin{array}{c}\text { Manfaat } \\
\text { Penggunaan }\end{array}$} & 1 & 0,653 & 0,000 & Valid \\
\hline & 2 & 0,586 & 0,000 & Valid \\
\hline & 3 & 0,666 & 0,000 & Valid \\
\hline & 4 & 0,664 & 0,000 & Valid \\
\hline & 5 & 0,606 & 0,000 & Valid \\
\hline & 6 & 0,641 & 0,000 & Valid \\
\hline & 7 & 0,679 & 0,000 & Valid \\
\hline \multirow{8}{*}{$\begin{array}{l}\text { Minat } \\
\text { Belajar }\end{array}$} & 1 & 0,561 & 0,000 & Valid \\
\hline & 2 & 0,506 & 0,002 & Valid \\
\hline & 3 & 0,512 & 0,000 & Valid \\
\hline & 4 & 0,505 & 0,001 & Valid \\
\hline & 5 & 0,577 & 0,000 & Valid \\
\hline & 6 & 0,636 & 0,000 & Valid \\
\hline & 7 & 0,575 & 0,000 & Valid \\
\hline & 8 & 0,884 & 0,000 & Valid \\
\hline \multirow{8}{*}{$\begin{array}{l}\text { Motivasi } \\
\text { Belajar }\end{array}$} & 1 & 0,604 & 0,000 & Valid \\
\hline & 2 & 0,515 & 0,002 & Valid \\
\hline & 3 & 0,598 & 0,000 & Valid \\
\hline & 4 & 0,487 & 0,003 & Valid \\
\hline & 5 & 0,692 & 0,000 & Valid \\
\hline & 6 & 0,677 & 0,000 & Valid \\
\hline & 7 & 0,714 & 0,000 & Valid \\
\hline & 8 & 0,590 & 0,000 & Valid \\
\hline
\end{tabular}

Berdasarkan Tabel 4.1 dan 4.2 diketahui bahwa pertanyaan-pertanyaan pada variabel independen yaitu Kemudahan Penggunaan ( $\left.\mathrm{X}_{1}\right)$, Manfaat Pengggunaan $\left(\mathrm{X}_{2}\right)$, dan variabel dependen Minat Belajar ( $\left.\mathrm{Y}_{1}\right)$, Motivasi Belajar $\left(\mathrm{Y}_{2}\right)$, masing-masing mempunyai signifikan 
sebesar $0,000 . .$, maka dapat disimpulkan bahwa keseluruhan item pertanyaan (indikator) yang terdapat dalam seluruh variabel tersebut adalah valid, karena semua item pertanyaan mempunyai signifikan di bawah 0,05 persen.

\section{Uji Realiabilitas}

Uji reliabilitas adalah alat ukur untuk mengukur suatu kuesioer yang merupakan indikator dari variabel atau konstruk. Butir pertanyaan dikatakan reliabel atau andal apabila jawaban seseorang terhadap pertanyaan adalah konsisten. Suatu konstruk atau variabel dikatakan reliabel jika memberikan nilai Cronbach alpa $>0,60$. Hasil pengujian reliabilitas dapat dilihat pada tabel berikut:

Tabel 4.3

Uji Reliabilitas Jenis Kelamin Laki-Laki

\begin{tabular}{|c|c|c|c|c|c|}
\hline No & Variabel & $\begin{array}{c}\text { Cronbach's } \\
\text { Alpha }\end{array}$ & $>$ & Standar & Reliabilitas \\
\hline 1 & $\begin{array}{c}\text { Kemudahan } \\
\text { Penggunaan (X1) }\end{array}$ & 0,690 & $>$ & 0,600 & Reliabel \\
\hline 2 & $\begin{array}{c}\text { Manfaat } \\
\left.\text { Penggunaan( } \mathrm{X}_{2}\right)\end{array}$ & 0,674 & $>$ & 0,600 & Reliabel \\
\hline 3 & $\begin{array}{c}\text { Minat } \\
\text { Belajar (Y) }\end{array}$ & 0,767 & $>$ & 0,600 & Reliabel \\
\hline 4 & $\begin{array}{c}\text { Motivasi } \\
\text { Belajar (Y) }\end{array}$ & 0,748 & $>$ & 0,600 & Reliabel \\
\hline
\end{tabular}

Sumber : Data Olahan, 2019

Tabel 4.4

Uji Reliabilitas Jenis Kelamin Perempuan

\begin{tabular}{|c|c|c|c|c|c|}
\hline No & Variabel & $\begin{array}{c}\text { Cronbach's } \\
\text { Alpha }\end{array}$ & $>$ & Standar & Reliabilitas \\
\hline 1 & $\begin{array}{c}\text { Kemudahan } \\
\text { Penggunaan (X1) }\end{array}$ & 0,720 & $>$ & 0,600 & Reliabel \\
\hline 2 & $\begin{array}{c}\text { Manfaat } \\
\left.\text { Penggunaan( } \mathrm{X}_{2}\right)\end{array}$ & 0,719 & $>$ & 0,600 & Reliabel \\
\hline 3 & $\begin{array}{c}\text { Minat } \\
\text { Belajar (Y) }\end{array}$ & 0,660 & $>$ & 0,600 & Reliabel \\
\hline 4 & $\begin{array}{c}\text { Motivasi } \\
\text { Belajar (Y) }\end{array}$ & 0,725 & $>$ & 0,600 & Reliabel \\
\hline
\end{tabular}

Hasil pengujian Pada Tabel 4.3 dan 4.4 menunjukkan nilai Cronbach's alpha dari keseluruhan variabel adalah lebih besar dari 0,600, dapat disimpulkan bahwa semua item pertanyaan adalah reliabel karena semua item pertanyaan mempunyai nilai Cronbach's alpha diatas 0,600 .

\section{Uji Asumsi Klasik}

1) Uji Normalitas Residual

Uji normalitas residual ini menggunakan metode grafik P-P plot yang apabila penyebaran data menyebar sekitar garis dan mengikuti garis diagonal, maka residual pada model regresi tersebut terdistribusi secara normal. 
Gambar 4.1

Grafik P-P Plot Of Regression Standardized Residual

Normal P-P Plot Of Regression Standardized Residual

Jenis Kelamin Laki-Laki

Dependent Variabel : Minat Belajar

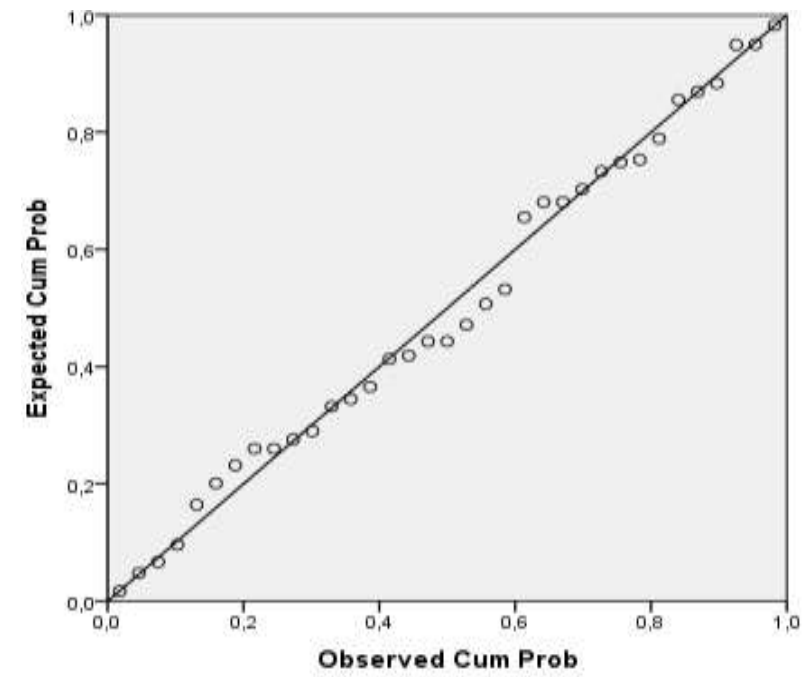

Sumber : Data Olahan, 2019

Gambar 4.2

Grafik P-P Plot Of Regression Standardized Residual

Normal P-P Plot Of Regression Standardized Residual

Jenis Kelamin Perempuan

Dependent Variabel : Motivasi Belajar

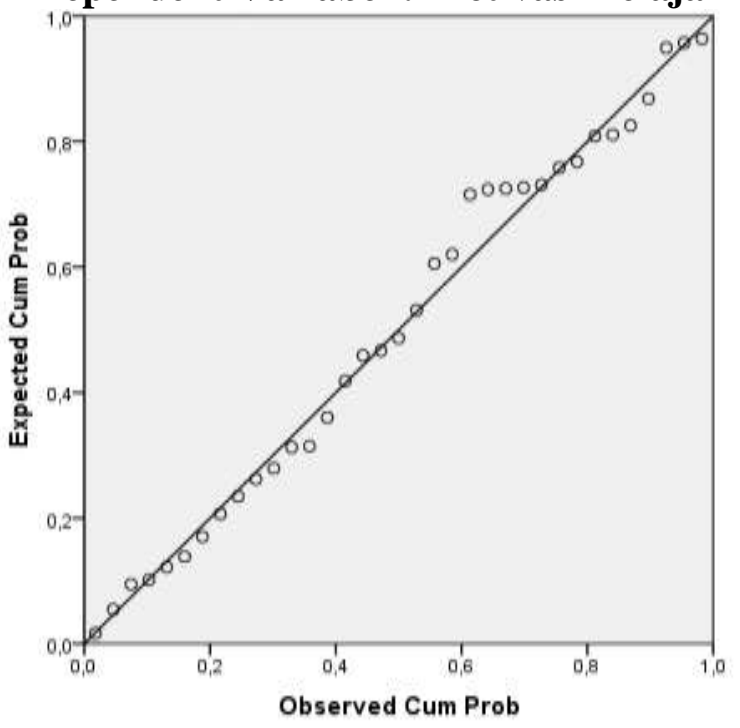

Sumber : Data Olahan, 2019

Tampilan pada grafik P-P Plot of Regression Standardized Residual pada Gambar 4.1 dan 4.2 di atas menunjukkan bahwa titik-titik (yang menggambarkan data sesungguhnya) terlihat menyebar disekitar garis diagonalnya. Hal ini menunjukkan bahwa model regresi sudah berdistribusi secara normal.

2) Uji Multikolinearitas 
Untuk menganalisis data dengan uji multikolinearitas yaitu apabila nilai VIF kurang dari 10 tolerance lebih dari 0,1 maka dinyatakan tidak terjadi multikolinearitas.

Tabel 4.5

Hasil Nilai Tolerance Dan Nilai Vif Coefficients (A) Jenis Kelamin Laki-Laki

Coefficients $^{\mathrm{a}}$

\begin{tabular}{|ll|r|r|}
\hline \multirow{2}{*}{\multicolumn{2}{|c|}{ Model }} & \multicolumn{2}{|c|}{ Collinearity Statistics } \\
\cline { 2 - 4 } & Tolerance & \multicolumn{1}{|c|}{ VIF } \\
\hline 1 & (Constant) & & \\
& X1 &, 980 & 1,020 \\
& X2 &, 980 & 1,020 \\
\hline
\end{tabular}

a. Dependent Variable: Y1

Tabel 4.6

Hasil Nilai Tolerance Dan Nilai Vif Coefficients (A) Jenis Kelamin Perempuan

Coefficients $^{\mathrm{a}}$

\begin{tabular}{|c|c|c|c|}
\hline \multirow{2}{*}{\multicolumn{2}{|c|}{ Model }} & \multicolumn{2}{|c|}{$\begin{array}{c}\text { Collinearity } \\
\text { Statistics } \\
\end{array}$} \\
\hline & & $\begin{array}{c}\text { Tolera } \\
\text { nce }\end{array}$ & VIF \\
\hline \multirow[t]{3}{*}{1} & (Constant) & & \\
\hline & $\mathrm{X} 1$ & ,918 & 1,089 \\
\hline & $\mathrm{X} 2$ & ,918 & 1,089 \\
\hline
\end{tabular}

a. Dependent Variable: Y1

Melihat hasil perhitungan yang terlihat pada Tabel 4.5 dan 4.6 diatas, dapat diketahui bahwa nilai VIF kedua variabel kurang dari 10. Untuk hasil Tolerance kedua variabel juga lebih besar dari 0,1, maka dapat disimpulkan bahwa model regresi tidak terjadi masalah multikolinearitas.

3) Uji Heterokedastisitas

Uji Heterokedastisitas dilakukan untuk mengetahui apakah dalam sebuah model regresi, terjadi ketidaksamaan varians dari residual suatu pengamatan ke pengamatan lain. Terjadi heterokedastisitas yaitu adanya titik-titik yang membuat dua buah garis lurus. Sumbu $\mathrm{X}$ adalah data $\mathrm{X}$ yang telah diprediksi dan sumbu $\mathrm{Y}$ adalah residual (Y prediksi - Y sesungguhnya) yang telah di standardized. Persamaan regresi yang baik jika tidak terjadi heterokedastisitas. Dari hasil output SPSS uji heterokedastisitas terdapat pada gambar 4.3 dan 4.4 Scatterplot sebagai berikut: 


\section{Gambar 4.3 \\ Grafik Scatterplot Jenis Kelamin Laki-Laki}

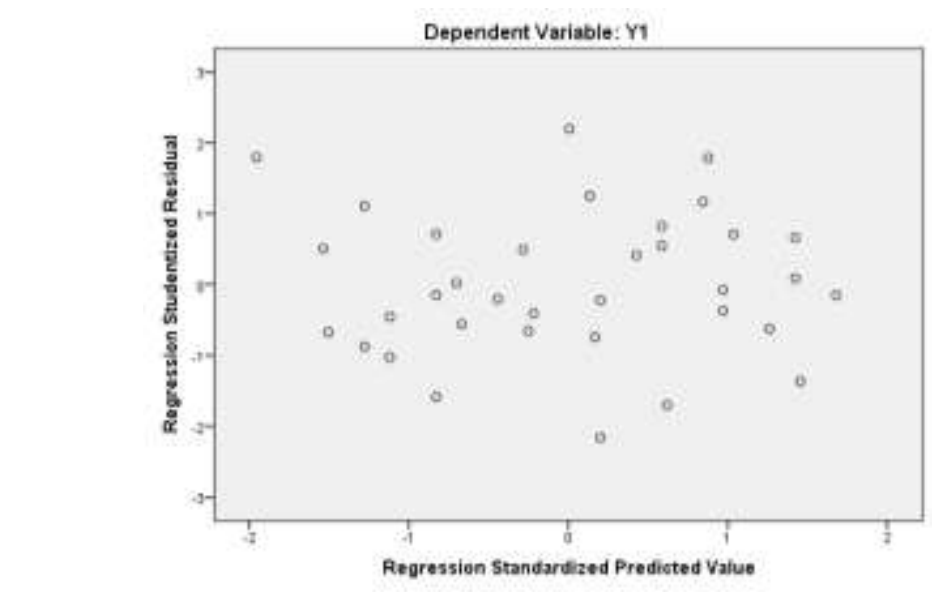

Sumber : Data Olahan, 2019

Gambar 4.4

Grafik Scatterplot Jenis Kelamin Perempuan

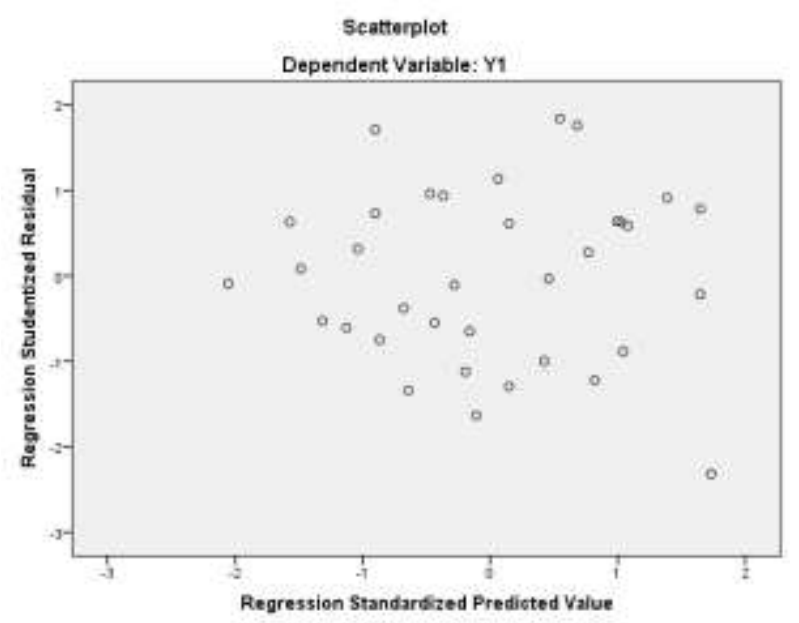

Sumber : Data Olahan, 2019

Dari grafik scatterplot pada Gambar 4.3 dan 4.4 di atas terlihat bahwa tidak ada pola yang teratur serta titik-titik menyebar secara acak di atas dan dibawah angka 0 pada sumbu Y. Hal ini dapat disimpulkan bahwa tidak terjadi heterokedastisitas pada model regresi, sehingga model regresi layak dipakai.

\section{Analisis Regresi Linier Berganda}

Analisis regresi linear berganda digunakan bertujuan untuk membuktikan hipotesis mengenai pengaruh variabel independen terhadap variabel dependen. Dengan demikian, dapat dianalisis apakah terdapat pengaruh antara variabel independen terhadap variabel dependen. Variabel independen tersebut mempunyai arah positif dalam pengaruhnya apabila nilai $t$ menunjukkan nilai yang positif. 
Tabel 4.7

Uji Regresi Linear Jenis Kelamin Laki-Laki

Coefficients $^{\mathrm{a}}$

\begin{tabular}{|c|c|c|c|c|c|}
\hline \multirow[b]{2}{*}{ Model } & \multicolumn{2}{|c|}{ Unstandardized Coefficients } & $\begin{array}{l}\text { Standardized } \\
\text { Coefficients }\end{array}$ & \multirow[b]{2}{*}{$\mathrm{t}$} & \multirow[b]{2}{*}{ Sig. } \\
\hline & $\mathrm{B}$ & Std. Error & Beta & & \\
\hline 1 (Constant) & 3,015 & 9,619 & & ,313 &, 756 \\
\hline $\mathrm{X} 1$ & ,719 & ,314 & ,305 & 2,289 & ,029 \\
\hline $\mathrm{X} 2$ & 1,333 & 279 & ,636 & 4,770 &, 000 \\
\hline
\end{tabular}

a. Dependent Variable: $\mathrm{Y}_{1}$

\section{Coefficients $^{\mathrm{a}}$}

\begin{tabular}{|c|c|c|c|c|c|}
\hline \multirow[b]{2}{*}{ Model } & \multicolumn{2}{|c|}{ Unstandardized Coefficients } & $\begin{array}{l}\text { Standardized } \\
\text { Coefficients }\end{array}$ & \multirow[b]{2}{*}{$\mathrm{t}$} & \multirow[b]{2}{*}{ Sig. } \\
\hline & $\mathrm{B}$ & Std. Error & Beta & & \\
\hline $\begin{array}{ll}1 & \text { (Constant) } \\
& \text { Y1 }\end{array}$ & $\begin{array}{r}17,804 \\
, 605\end{array}$ & $\begin{array}{r}2,404 \\
, 090\end{array}$ & 759, & $\begin{array}{l}7,405 \\
6,689\end{array}$ & $\begin{array}{l}, 000 \\
, 000\end{array}$ \\
\hline
\end{tabular}

a. Dependent Variable: $\mathrm{Y}_{2}$

Model persamaan regresi yang dapat dituliskan dari hasil tersebut dalam bentuk persamaan regresi sebagai berikut:

$\mathrm{Y}=3,015+0,305 \mathrm{X}_{1}+0,636 \mathrm{X}_{2}$

a. Koefisien regresi variabel kemudahan penggunaan $\left(\mathrm{X}_{1}\right)$ berpengaruh terhadap minat belajar (Y1) dengan nilai koefisien sebesar 0,305 dan nilai signifikan sebesar 0,029<0,05.

b. Koefisien regresi variabel manfaat penggunaan $\left(\mathrm{X}_{2}\right)$ berpengaruh terhadap minat belajar (Y1) dengan nilai koefisien sebesar 0,636 dan nilai signifikan sebesar 0,000 0,05.

c. Koefisien regresi variabel minat belajar $\left(\mathrm{Y}_{1}\right)$ berpengaruh terhadap motivasi belajar $\left(\mathrm{Y}_{2}\right)$ dengan nilai koefisien sebesar 0,759 dan nilai signifikan sebesar 0,000 $<0,05$.

Tabel 4.8

Uji Regresi Linear Jenis Kelamin Perempuan

Coefficients $^{\mathrm{a}}$

\begin{tabular}{|l|r|r|r|r|r|}
\hline & \multicolumn{2}{|c|}{} & \multicolumn{2}{|c|}{$\begin{array}{c}\text { Standardized } \\
\text { Coefficients }\end{array}$} & \\
\cline { 2 - 4 } Model & \multicolumn{1}{|c|}{ Unstandardized Coefficients } & Std. Error & Beta & \multicolumn{1}{c|}{ S } \\
\hline 1 (Constant) & 22,071 & 3,978 & & 5,548 &, 000 \\
X1 &, 099 &, 136 &, 117 &, 729 &, 472 \\
X2 &, 357 &, 131 &, 439 & 2,726 &, 010 \\
\hline
\end{tabular}

a. Dependent Variable: $\mathrm{Y}_{1}$

Coefficients $^{\mathrm{a}}$

\begin{tabular}{|c|c|c|c|c|c|}
\hline \multirow[b]{2}{*}{ Model } & \multicolumn{2}{|c|}{ Unstandardized Coefficients } & $\begin{array}{l}\text { Standardized } \\
\text { Coefficients }\end{array}$ & \multirow[b]{2}{*}{$\mathrm{t}$} & \multirow[b]{2}{*}{ Sig. } \\
\hline & B & Std. Error & Beta & & \\
\hline $1 \quad$ (Constant) &, 356 & 7,459 & & ,048 & ,962 \\
\hline Y1 & ,794 & 215 &, 540 & 3,684 & 001 \\
\hline
\end{tabular}

a. Dependent Variable: $\mathrm{Y}_{2}$ 
a. Koefisien regresi variabel kemudahan penggunaan $\left(\mathrm{X}_{1}\right)$ tidak berpengaruh terhadap minat belajar $\left(\mathrm{Y}_{1}\right)$ dengan nilai koefisien sebesar 0,117 dan nilai signifikan sebesar 0,472>0,05.

b. Koefisien regresi variabel manfaat penggunaan $\left(\mathrm{X}_{2}\right)$ berpengaruh positif terhadap minat belajar $\left(\mathrm{Y}_{1}\right)$ dengan nilai koefisien sebesar 0,439 dan nilai signifikan sebesar 0,010<0,05.

c. Koefisien regresi variabel minat belajar $\left(\mathrm{Y}_{1}\right)$ berpengaruh terhadap motivasi belajar $\left(\mathrm{Y}_{2}\right)$ dengan nilai koefisien sebesar 0,540 dan nilai signifikan sebesar 0,001 $<0,05$.

\section{Uji Model}

a. Uji Simultan (Uji Statistik F)

Uji $\mathrm{F}$ digunakan untuk mengetahui pengaruh variabel bebas secara bersama-sama (simultan) terhadap variabel terikat.

Kaidah pengajian signifikan:

Jika nilai sig $>0,05$ maka tidak memiliki pengaruh signifikan

Jika nilai sig $<0,05$ maka memiliki pengaruh signifikan

Tabel 4.9

Hasil Uji Simultan (Uji Statistik F)

Jenis Kelamin Laki-Laki

ANOVA $^{\text {a }}$

\begin{tabular}{|c|c|c|c|c|c|}
\hline Model & $\begin{array}{l}\text { Sum of } \\
\text { Squares }\end{array}$ & df & Mean Square & $\mathrm{F}$ & Sig. \\
\hline 1 Regression & 345,781 & 2 & 172,891 & 12,713 &, $000^{b}$ \\
\hline Residual & 435,190 & 32 & 13,600 & & \\
\hline Total & 780,971 & 34 & & & \\
\hline
\end{tabular}

a. Dependent Variable: $\mathrm{Y}_{1}$

b. Predictors: (Constant), $\mathrm{X}_{2}, \mathrm{X}_{1}$

Tabel 4.10

Hasil Uji Simultan (Uji Statistik F)

Jenis Kelamin Perempuan

ANOVA $^{\mathrm{a}}$

\begin{tabular}{|c|c|c|c|c|c|}
\hline Model & $\begin{array}{l}\text { Sum of } \\
\text { Squares }\end{array}$ & Df & Mean Square & $\mathrm{F}$ & Sig. \\
\hline 1 Regression & 45,100 & 2 & 22,550 & 4,957 &, $013^{b}$ \\
\hline Residual & 145,586 & 32 & 4,550 & & \\
\hline Total & 190,686 & 34 & & & \\
\hline
\end{tabular}

a. Dependent Variable: $\mathrm{Y}_{1}$

b. Predictors: (Constant), $\mathrm{X}_{2}, \mathrm{X}_{1}$

Berdasarkan hasil uji $\mathrm{F}$ pada tabel 4.9 di atas diketahui bahwa nilai $\mathrm{F}$ sebesar 12,713 dengan nilai signifikan sebesar 0,000 maka $\mathrm{H}_{1}$ diterima sedangkan $\mathrm{H}_{0}$ ditolak. Artinya diterimanya $\mathrm{H}_{1}$ menunjukkan bahwa secara bersama-sama variabel kemudahan penggunaan dan manfaat penggunaan internet mempunyai pengaruh yang positif terhadap minat belajar pada mahasiswa STIE Mulia Singkawang. Sedangkan pada tabel 4.10 di atas diketahui bahwa nilai $F$ sebesar 4,957 dengan nilai signifikan sebesar 0,013 maka $\mathrm{H}_{1}$ diterima sedangkan $\mathrm{H}_{0}$ ditolak. Artinya diterimanya $\mathrm{H}_{1}$ menunjukkan bahwa secara bersama-sama variabel kemudahan 
penggunaan dan manfaat penggunaan internet mempunyai pengaruh yang positif terhadap minat belajar pada mahasiswi STIE Mulia Singkawang.

b. Uji Parsial (Uji t)

Tabel 4.11

Hasil Perhitungan Koefisien Determinan

Jenis Kelamin Laki-Laki

Model Summary

\begin{tabular}{|l|r|r|r|r|}
\hline Model & $\mathrm{R}$ & R Square & $\begin{array}{l}\text { Adjusted } \\
\text { R Square }\end{array}$ & $\begin{array}{c}\text { Std. Error of the } \\
\text { Estimate }\end{array}$ \\
\hline 1 &, $665^{\mathrm{a}}$ &, 443 &, 408 & 3,688 \\
\hline
\end{tabular}

a. Predictors: (Constant), $\mathrm{X}_{2}, \mathrm{X}_{1}$

Model Summary

\begin{tabular}{|c|c|c|c|c|}
\hline Model & $\mathrm{R}$ & R Square & $\begin{array}{c}\text { Adjuste } \\
\text { d R } \\
\text { Square }\end{array}$ & $\begin{array}{c}\text { Std. Error of the } \\
\text { Estimate }\end{array}$ \\
\hline 1 &, $759^{\mathrm{a}}$ & ,575 & ,563 & 2,526 \\
\hline
\end{tabular}

a. Predictors: (Constant), $\mathrm{Y}_{1}$

Dapat diketahui dari hasil olah data di atas, bahwa nilai koefisien determinasi $\left(\mathrm{R}^{2}\right)$ sebesar 0,443. Dari nilai tersebut dapat dilihat bahwa minat belajar mahasiswa dipengaruhi oleh variabel kemudahaan penggunaan dan manfaat pengggunaan sebesar 44,3 persen dan sisanya 55,7 persen dipengaruhi oleh faktor-faktor lainnya dan $\left(\mathrm{R}^{2}\right)$ sebesar 0,575 berarti motivasi belajar mahasiswa dipengaruhi oleh variabel minat belajar sebesar 57,5 persen dan sisanya 42,5 dipengaruhi oleh faktor-faktor lainnya.

Tabel 4.12

\section{Hasil Perhitungan Koefisien Determinan}

Jenis Kelamin Perempuan

Model Summary

\begin{tabular}{|l|l|r|r|r|}
\hline Model & R & R Square & Adjusted R Square & \multicolumn{2}{|c|}{$\begin{array}{c}\text { Std. Error of the } \\
\text { Estimate }\end{array}$} \\
\hline 1 &, $486^{\mathrm{a}}$ &, 237 &, 189 & 2,133 \\
\hline
\end{tabular}

a. Predictors: (Constant), $X_{2}, X_{1}$

\begin{tabular}{|l|c|r|r|c|}
\hline Model & R & R Square & Adjusted R Square & $\begin{array}{c}\text { Std. Error of the } \\
\text { Estimate }\end{array}$ \\
\hline 1 &, $540^{\mathrm{a}}$ &, 291 &, 270 & 2,975 \\
\hline
\end{tabular}

a. Predictors: (Constant), $\mathrm{Y}_{1}$

Dapat diketahui dari hasil olah data di atas, bahwa nilai koefisien determinasi $\left(\mathrm{R}^{2}\right)$ sebesar 0,237. Dari nilai tersebut dapat dilihat bahwa minat belajar mahasiswi dipengaruhi oleh variabel kemudahaan penggunaan dan manfaat pengggunaan sebesar 23,7 persen dan sisanya 76,4 persen dipengaruhi oleh faktor-faktor lainnya dan $\left(\mathrm{R}^{2}\right)$ sebesar 0,291 berarti motivasi 
belajar mahasiswi dipengaruhi oleh variabel minat belajar sebesar 29,1 persen dan sisanya 70,9 dipengaruhi oleh faktor-faktor lainnya.

\section{KESIMPULAN}

Berdasarkan hasil analisis data yang dilakukan, maka kesimpulan dari penelitian ini adalah:

1) Ketiga hipotesis mempunyai estimasi atau loading factor yang positif sehingga hasilnya semua hipotesis dapat diterima.

2) Pertanyaan-pertanyaan pada variabel independen yaitu Kemudahan Penggunaan ( $\left.X_{1}\right)$, Manfaat Pengggunaan $\left(\mathrm{X}_{2}\right)$, dan variabel dependen Minat Belajar $\left(\mathrm{Y}_{1}\right)$, Motivasi Belajar $\left(\mathrm{Y}_{2}\right)$, masing-masing mempunyai signifikan sebesar $0,000 .$. , maka dapat disimpulkan bahwa keseluruhan item pertanyaan (indikator) yang terdapat dalam seluruh variabel tersebut adalah valid

3) Hasil pengujian menunjukkan nilai Cronbach's alpha dari keseluruhan variabel adalah lebih besar dari 0,600, dapat disimpulkan bahwa semua item pertanyaan adalah reliabel karena semua item pertanyaan mempunyai nilai Cronbach's alpha diatas 0,600.

4) Grafik P-P Plot of Regression Standardized Residual menunjukkan bahwa titik-titik (yang menggambarkan data sesungguhnya) terlihat menyebar disekitar garis diagonalnya. Hal ini menunjukkan bahwa model regresi sudah berdistribusi secara normal.

5) Hasil Tolerance pada uji multikolinearitas lebih besar dari 0,1, maka dapat disimpulkan bahwa model regresi tidak terjadi masalah multikolinearitas.

6) Kemudahan penggunaan dan manfaat penggunaan internet berpengaruh terhadap minat belajar mahasiswa dengan nilai signifikansi 0,029 dan 0,000. Dan minat belajar berpengaruh terhadap motivasi belajar mahasiswa dengan nilai signifikansi 0,00 .

7) Kemudahan penggunaan tidak berpengaruh terhadap minat belajar mahasiswi akan tetapi kemudahan penggunaan internet berpengaruh terhadap minat belajar mahasiswi dengan nilai signifikansi 0,472 dan 0,010. Dan minat belajar mahasiswi mempengaruhi motivasi belajar mahasiswi dengan nilai signifikansi 0,001

8) Hasil uji $\mathrm{F}$ mahasiswa menunjukkan bahwa nilai $\mathrm{F}$ sebesar 12,713 dengan nilai signifikansi sebesar 0,000 maka $\mathrm{H}_{1}$ diterima sedangkan $\mathrm{H}_{0}$ ditolak. Artinya secara bersama-sama variabel kemudahan penggunaan dan manfaat penggunaan internet mempunyai pengaruh yang positif terhadap minat belajar pada mahasiswa STIE Mulia Singkawang. Sedangkan hasil uji $\mathrm{F}$ mahasiswi menunjukkan bahwa nilai $\mathrm{F}$ sebesar 4,957 dengan nilai signifikan sebesar 0,013 maka $\mathrm{H}_{1}$ diterima sedangkan $\mathrm{H}_{0}$ ditolak. Artinya secara bersama-sama variabel kemudahan penggunaan dan manfaat penggunaan internet mempunyai pengaruh yang positif terhadap minat belajar pada mahasiswi STIE Mulia Singkawang.

9) Pada uji t mahasiswa menunjukkan bahwa nilai koefisien determinasi $\left(\mathrm{R}^{2}\right)$ sebesar 0,443 artinya minat belajar mahasiswa dipengaruhi oleh variabel kemudahaan penggunaan dan manfaat pengggunaan sebesar 44,3 persen dan sisanya 55,7 persen dipengaruhi oleh faktor-faktor lainnya dan $\left(\mathrm{R}^{2}\right)$ sebesar 0,575 berarti motivasi belajar mahasiswa dipengaruhi oleh variabel minat belajar sebesar 57,5 persen dan sisanya 42,5 dipengaruhi oleh faktor-faktor lainnya.

10) Pada uji $t$ mahasiswi menunjukkan bahwa nilai koefisien determinasi $\left(R^{2}\right)$ sebesar 0,237, artinya minat belajar mahasiswi dipengaruhi oleh variabel kemudahaan penggunaan dan manfaat pengggunaan sebesar 23,7 persen dan sisanya 76,4 persen 
dipengaruhi oleh faktor-faktor lainnya dan $\left(\mathrm{R}^{2}\right)$ sebesar 0,291 berarti motivasi belajar mahasiswi dipengaruhi oleh variabel minat belajar sebesar 29,1 persen dan sisanya 70,9 dipengaruhi oleh faktor-faktor lainnya.

\section{SARAN}

Berdasarkan hasil penelitian yang dilakukan, maka peneliti memberikan saran-saran yaitu:

1. Dengan adanya kemudahan dan manfaat penggunaan internet diharapkan STIE Mulia Singkawang dapat mengambil kebijakan yang baik guna kemajuan yang akan datang,

2. Kepada mahasiswa dapat lebih sering memanfaatkan internet untuk mencari berbagai informasi/referensi tentang perkuliahan, dimana hal tersebut akan menimbulkan minat seseorang untuk belajar dan lebih termotivasi dalam menggunakan internet sebagai media pembelajaran.

3. Kepada peneliti-peneliti lain yang menjadikan penelitian ini sebagai referensi disarankan untuk mencari model yang lebih baik agar hasil yang harapkan dapat tercapai dengan baik.

\section{DAFTAR PUSTAKA}

Davis, F. D. 1989. Percieved Usefulness, Percieved Ease of Use, and User Acceptance of Information Technology. Miss Quarterly.

Dimyati dan Mudjiono. 2009. Belajar dan Pembelajaran. PT Rineka Cipta. Jakarta

Djaali. 2013. Psikologi Pendidikan. Jakarta. Bumi Aksara

Greenlaw, R., \& Hepp, E. 2002. Fundamentals of the Internet and The World Wide Web. McGraw Hill. New York

Hamzah, B. U. 2008. Profesi Kependidikan. Bumi Aksara. Jakarta.

Hanifah, \& Abdullah, S. 2001. Pengaruh Perilaku Belajar Terhadap Prestasi Akademik Mahasiswa Akuntansi. Media Riset Akuntansi, Auditing dan Informasi, 63-68.

Jihad, A., dan Haris, A. 2012. Evaluasi Pelajaran. Multi Pressindo. Yogyakarta

Jogiyanto, H. M. 2007. Sistem Informasi Keperilakuan. Edisi Revisi. Andi Publisher. Yogyakarta

Khairani, M. 2014. Psikologi Belajar. Aswaja Pressindo. Yogyakarta

Priyatno, D. 2016. Belajar Alat Analisis Data dan Cara Pengolahannya dengan SPSS. Gava Media. Yogyakarta

Ricoida, D.I, dan Pibriana, D. 2016. Pengaruh Penggunaan Internet Terhadap Minat Dan Perilaku Belajar Mahasiswa. Seminar Nasional Sistem Informasi Indonesia

Sardiman. 2011. Interaksi dan Motivasi Belajar Mengajar. PT Raja Grafindo Persada. Jakarta

Slameto. 2003. Belajar dan Faktor. Rineka Cipta. Jakarta

Sugiyono. 2013. Metode Penelitian Manajemen, cetakan kesatu. Alfabeta. Bandung

Tjahjono, H. K., \& Wulandari, Y. 2008. Implementasi Model Penerimaan Teknologi Pada Organisasi: Kajian Intensi Dosen Menggunakan Teknologi E-Learning. Jurnal Ekonomi dan Bisnis 20(1), 42-51.

Widiatika, I., \& Sensuse, D. 2008. Pengembangan Model Penerimaan Teknologi Internet Oleh Pelajar Dengan Menggunakan Konsep Technology Acceptance Model (TAM), Jurnal Sistem Informasi MT -UI, 81-92.

Winarno, W. W. 2004. Sistem Informasi Manajemen. UPP AMP YKPN. Yogyakarta 